\title{
Royal Family Members and Financial Reporting Timeliness: Evidence from UAE
}

\author{
Mohammed Ali Almuzaiqer, A.A. Fatima, Maslina Ahmad \\ Department of Accounting, Kulliyyah of Economics and Management Sciences, International \\ Islamic University Malaysia
}

\begin{abstract}
This study aims to examine the relationship between Royal family members on the board of directors and financial reporting timeliness among listed companies in the United Arab Emirates (UAE). UAE has two markets, namely Abu Dhabi Exchange Security (ADX) and Dubai Financial Market (DFM). The data of the current study were collected from these two markets listed companies for the periods of 2011 to 2018 which resulted in 437 firm- year sample data. The results of this study showed that the existence of royal family members on the board of the UAE listed companies is significantly associated with financial reporting timeliness. This study provides evidence on the role played by the elite groups (Royal Family members) in UAE in enhancing the role of the board of directors. The findings also reported that board independence, audit committee size, audit committee expert, and firm profitability are significantly associated with financial reporting timeliness. The findings of this study contribute to the existing theory and empirical evidence of how the existence of Royal family members on the board of directors adds values to the company and improves its financial reporting quality.
\end{abstract}

Keywords- Royal family members, board of directors, financial reporting timeliness, United Arab Emirates (UAE) 
The board of directors of a company has an important number of tasks and responsibilities such as establishing the policies and objectives. The board also has the role to control and monitor the operations and activities of the company, which is essential to the decision-making process (Alghamdi, 2012). According to agency theory, the main responsibilities of the board of directors is to monitor the management in enhancing the value of the firms and improve financial reporting quality (Fama \& Jensen, 1983). Furthermore, controlling role is essential since protecting the shareholders' interests is one of the critical responsibilities of the board of directors. Although the managers are assigned to take the majority of management-related decisions, the board of directors is still considered the cornerstone of controlling by monitoring and approving significant managerial decisions (Al-Adeem \& Al-Sogair, 2019).

Based on the agency theory, the directors represent shareholders' interests and their monitoring roles emphasize the decision-making process to avoid issues between management and shareholders. To improve the role of the board's supervision on management, agency theory suggests the existence of a higher proportion of external directors of the board (Alrassas \& Kamardin, 2015).

The International Accounting Standards Board (2018) argued that financial reporting is a channel that helps the company to provide information to investors to make their economic decisions. For this information to have economic values, it has to be provided in a timely basis (Hassan, 2016). Consequently, financial markets in many countries determine a specific period for companies to submit their financial reporting; otherwise, penalties are imposed against the companies with late submission of financial reporting by the capital market authorities.

In the United Arab Emirates (UAE), there are two financial markets. They are Abu Dhabi Exchange Security (ADX) and Dubai Financial Market (DFM). Both markets were established in 2000. The quality of financial reporting of these two markets is still questionable since they are considered new with only two decades old. The reporting requirements are not as strong as in the established markets. Therefore, the quality of financial statements may be weaker than in other countries. In other words, it can be stated that the quality of financial reporting in developing countries is expected to be more essential because the regulations in developing economies are less efficient compared to the developed economies (Almuzaiqer et al., 2018).

Furthermore, like other Gulf countries, the UAE is ruled and controlled by Royal families. Royal family's members have special seats on the board of directors in many companies. Due to the uniqueness of the political regime in the UAE, this study aims to investigate the influence of the existence of Royal family members on the board on financial reporting quality. The current study argues that when the Royal family members serve on the board, they work for the best interest of shareholders and enhance financial reporting quality. This is because many of Royal family members are appointed as managers and the management work properly when they are monitored closely by the Royal family members. Therefore, the management tries to submit the financial report on a timely basis.

Accordingly, elitism theory argues that the elite's members in the society have power and they influence the non-elite people who are powerless (López, 2013). Peterson (2001) stated that the ruling families in Gulf countries, including the UAE, are considered the top elite group which exercises both political and economic power. Many of the Royal family members in the UEA companies are appointed as directors of boards who may influence the management behaviours. Thus, they help to improve financial reporting quality (Alazzani et al., 2019). This study will contribute to the financial reporting quality literature by providing new evidence concerning the effect of Royal family members on financial reporting timeliness. Hence, the objective of the current study is to offer empirical evidence regarding the 
determinants of financial reporting timeliness in the UAE with a specific focus to the Royal family members' roles on the board of directors.

This paper is organized into several sections. Section one is the introduction to the study. Section two discusses the concept of financial reporting timeliness and its relation to financial reporting quality. Section three discusses the literature review and hypotheses development. The research methodology is described in section four. Section five and six highlight the model specification and study results of the study respectively. Finally, the conclusion and implications are provided in the last section.

\section{FINANCIAL REPORTING TIMELINESS AND FINANCIAL REPORTING QUALITY}

Financial reporting quality can be measured in term of qualitative characteristics of financial information (Beest et al., 2009). There are fundamental and enhancing characteristics of financial information. Timeliness is one of enhancing characteristics. Financial reporting is recognized as an important channel that helps investors and other users of financial reporting to make economic decisions. Hence, many countries around the world have set a time frame for companies within which to submit their financial reporting; otherwise, penalties are imposed (Almuzaiqer, 2016).

Previous studies divided financial reporting timeliness to total reporting timeliness (TRT) and audit reporting lag (ARL). TRT refers to the time taken to issue financial statements to the public users, whereas ARL refers to the time taken by the auditors to issue the audited financial statements. The current study used TRT as a proxy of financial reporting timeliness. This measure was previously used by Al-Ajmi (2008) and Baatwah (2014).

\section{LITERATURE REVIEW AND HYPOTHESES DEVELOPMENT}

The homogeneity among the board of directors hinders the directors from serving as active monitors, engaging in critical thinking, and making informed decisions (Baatwah, 2014). Thus, the diversity of the board may help the directors to do their managerial duties properly. The membership of the Royal family members on the board of directors is classified as a race diversity. Arioglu (2020) stated that board diversity helps to better monitoring management and enhance the firm value. Almost similarly, Clark (2004) argued that there is a circumstance when several individuals are more powerful than others which indicate that they have the power to affect others' actions and points of views. Furthermore, Alghamdi (2012) reported that a number of the Royal family members in Saudi Arabia have special seats in the board of directors and engaged in managerial duties which allow them to monitor the management carefully, hence reduce poor management and potential misbehaviours. Moreover, Alzharani and Che-Ahmad (2015) investigated the association between the existence of the Royal family members on the board of directors and firm performance. By using a sample of 573 Saudi listed companies, the results showed that firm performance is positively associated with the existence of the Royal family on the board of directors. This indicates that Royal family members play a vital role in reducing asymmetric information in Saudi firms.

Furthermore, Habtoor and Ahmad (2017), investigated the effect of the existence of the Royal family members on the board of directors on the corporate risk disclosure by using the same setting. Based on company-year observations, the study examined 307 Saudi Arabia firms and reported that corporate risk disclosure is positively affected by the existence of the Royal family members on the board of directors. This result indicates that the Royal family members have the main tool to monitor the management and they have more influence on the board of directors compared to others. The study argued 
that the members of Royal families obtain their power from being a part of the government and their relationship with the ruling bodies.

Moreover, Alazzani et al. (2019) studied the influence of Royal family members on corporate social responsibility (CSR) in the Gulf countries for the periods of 2010-2016. The findings showed that the existence of Royal family members on the board of directors is positively associated with CSR disclosure. This result indicates that Royal family members take their responsibility toward their communities and this is reflected in the financial reporting disclosure. In summary, the literature suggests that the existence of Royal family members on the board of directors helps in enhancing corporate risk disclosure, firm performance and reducing the wrongdoing actions by the managers. Based on the previous studies and elite theory, this study argues that Royal family members on the boards of UAE companies play an important role in enhancing the quality of decision-making process and prevent inappropriate behaviours of management in an earlier stage, which subsequently results in improving financial reporting timeliness. Thus, the hypothesis of the study is expressed as follow:

H1: There is a negative relationship between the existence of Royal family members on the board of directors and financial reporting timeliness.

\section{RESEARCH DESIGN AND METHODOLOGY}

\section{Sample and Data}

This study used secondary data as the main source to collect the data. An unbalanced panel method was used to collect the data for the periods of 2011-2018. The sample of the study is all the population of the companies listed in ADX and DFM financial markets. The data of companies listed in ADX and DFM were obtained from the ADX and DFM websites. Table 1 presents a summary of the distribution of listed companies and the study sample.

Table 1: Distribution of Listed Companies in ADX and DFM Markets

\begin{tabular}{|c|c|c|c|c|c|c|c|c|c|c|}
\hline \multirow[t]{2}{*}{ Sector } & \multicolumn{6}{|c|}{ Years } & & & \multirow[t]{2}{*}{ Total } & \multirow[t]{2}{*}{$\%$} \\
\hline & 2011 & 2012 & 2013 & 2014 & 2015 & 2016 & 2017 & 2018 & & \\
\hline Financial & 61 & 61 & 62 & 63 & 63 & 66 & 67 & 76 & 519 & $52.3 \%$ \\
\hline Construction and Real Estate & 12 & 12 & 12 & 13 & 14 & 14 & 14 & 13 & 104 & $10.8 \%$ \\
\hline Trading & 9 & 9 & 9 & 11 & 11 & 11 & 12 & 11 & 83 & $8.5 \%$ \\
\hline Services & 17 & 17 & 17 & 18 & 18 & 18 & 18 & 21 & 144 & $14.6 \%$ \\
\hline Industrials & 15 & 15 & 16 & 16 & 16 & 16 & 18 & 14 & 126 & $13.3 \%$ \\
\hline Joint stock & 0 & 0 & 0 & 0 & 1 & 1 & 2 & 2 & 6 & $0.3 \%$ \\
\hline TOTAL & 114 & 114 & 116 & 121 & 123 & 126 & 131 & 137 & 982 & $100 \%$ \\
\hline \multicolumn{11}{|l|}{ Excluded } \\
\hline Financial firms & (61) & (61) & $(62)$ & (63) & (63) & $(66)$ & (67) & (76) & (519) & $(53 \%)$ \\
\hline Missing Observations & $(1)$ & $(1)$ & $(2)$ & $(5)$ & $(2)$ & $(2)$ & $(7)$ & $(6)$ & $(26)$ & $(2 \%)$ \\
\hline Final Sample & 52 & 52 & 52 & 53 & 58 & 58 & 57 & 55 & 437 & $45 \%$ \\
\hline
\end{tabular}

The initial 982 firm-year observations are shown in Table 1. From the total of 982 observations, 519 observations were excluded because they belong to the financial sector, have unique business environments, and monitored by different authorities (Bamber et al., 1993); while 26 firm- year observations were also excluded from the study sample because they have missing data. The final data is 437 non-financial observations covering the periods of 2011 to 2018. Table 2 shows the distribution of the sample based on the industry sectors. 
Table 2: Distribution of study sample

\begin{tabular}{|c|c|c|c|c|c|c|c|c|c|c|}
\hline \multirow[t]{2}{*}{ Sector } & \multicolumn{6}{|c|}{ Years } & & & \multirow[t]{2}{*}{ Total } & \multirow[t]{2}{*}{$\%$} \\
\hline & 2011 & 2012 & 2013 & 2014 & 2015 & 2016 & 2017 & 2018 & & \\
\hline Construction andReal Estate & 9 & 9 & 9 & 10 & 13 & 13 & 13 & 12 & 88 & $20.1 \%$ \\
\hline Trading & 9 & 9 & 9 & 9 & 11 & 11 & 11 & 11 & 80 & $18.3 \%$ \\
\hline Industrials & 15 & 15 & 15 & 15 & 15 & 14 & 13 & 13 & 115 & $26.3 \%$ \\
\hline Services & 19 & 19 & 19 & 19 & 19 & 20 & 20 & 19 & 154 & $35.2 \%$ \\
\hline Final Sample & 52 & 52 & 52 & 53 & 58 & 58 & 57 & 55 & 437 & $100 \%$ \\
\hline
\end{tabular}

\section{Variables Measurement}

Financial reporting timeliness was used as a measurement of financial reporting quality. This proxy is applied by many studies such as Yasin and Nelson's (2012). The Total Reporting Timelines (TRT) was used as a proxy of financial reporting timeliness which refers to the number of days between the year-end date and the date when the financial reports are submitted to ADX and DFM websites.

Table 3 summaries the variables included in the empirical model.

Table 3: Variables included in the study model

\begin{tabular}{|c|c|c|}
\hline Variables & Acronym & Measurement \\
\hline $\begin{array}{ll}\text { Total } & \text { reporting } \\
\text { timeliness } & \end{array}$ & TRT & $\begin{array}{l}\text { The number of days between the year-end date and the date when financial reports } \\
\text { submitted to ADX and DFM websites. }\end{array}$ \\
\hline Royal family members & ROYAL & 1 if at least one of Royal family members sits on the board of directors, otherwise 0. \\
\hline Board size & BOSIZ & The number of directors in the board \\
\hline Board independence & BOIND & $\begin{array}{l}\text { The proportion of independent directors on the } \\
\text { Board. }\end{array}$ \\
\hline Board Meeting & BOME & The number of meeting hold by the board in the year \\
\hline Audit committee size & ACSIZ & The number of members in audit committee \\
\hline $\begin{array}{l}\text { Audit committee } \\
\text { independence }\end{array}$ & ACIND & The percentage of independent members in the committee. \\
\hline $\begin{array}{ll}\text { Audit } & \text { Committee } \\
\text { Meeting } & \end{array}$ & & The number of meeting hold by the audit committee in the year \\
\hline Audit Committee Expert & & The total number of accounting experts on audit committee \\
\hline Firm size & SIZE & Total assets in its natural log. \\
\hline Profitability & PROF & ROA (The net income before interest and tax to the total assets). \\
\hline Leverage & LEVE & The ratio of total liabilities to total assets. \\
\hline
\end{tabular}

\section{MODEL SPECIFICATION AND VARIABLES MEASUREMENT}

A multivariate regression analysis was used to examine the association between Royal family members and audit reporting quality based on the following equation:

TRT $=\beta_{0}+\beta_{1}$ ROYAL $+\beta_{2}$ BOSIZ $+\beta_{3}$ BOIND $+\beta_{4}$ BOME $+\beta_{5}$ ACSIZ $+\beta_{6}$ ACIND $+\beta_{7}$ ACME $+\beta_{8}$ ACEXP $+\beta_{9}$ SIZE $+\beta_{10}$ PORF $+\beta_{11}$ LEVE $+\varepsilon$

Where: 
TRT $=$ The number of days between the year-end date and the date when financial reports submitted to ADX and DFM websites.

ROYAL $=1$ if at least one of the Royal family members sits on the board of directors, otherwise 0 .

BOSIZ $=$ The number of directors on the board

$\mathrm{BOIND}=$ The proportion of independent directors on the board

$\mathrm{BOME}=$ The number of meetings held by the board in the year

ACSIZ $=$ The number of members in audit committee

$\mathrm{ACIND}=$ The proportion of independent members in the committee.

$\mathrm{ACME}=$ The number of meetings held by the audit committee

$\mathrm{ACEXP}=$ The number of accounting expert in the audit committee.

$\mathrm{SIZE}=$ Total assets in its natural $\log$.

$\mathrm{PROF}=\mathrm{ROA}$ (The net income before interest and tax to the total assets).

LEVE $=$ The ratio of total liabilities to the total assets.

$\varepsilon=$ Error term.

Ten explanatory variables were used as controlled variables as found in the literature for their potential influence on financial reporting timeliness. These controlled variables included the board size, board independence, board meetings, audit committee size, audit committee independence, audit committee meetings, audit committee expertise, firm size, firm profitability, and firm leverage.

For board size (BODSIZ), it has been argued that a large-sized board can provide more skills and proficiency to solve problems, so they are more likely to be effective in monitoring the management function (Baatwah 2014). Ghazali (2010) also reported that a large board is expected to offer a diversity in terms of expertise and skills which help in oversee the management and improve financial reporting quality. Moreover, Merendino and Melville (2019) found that a large board is positively associated with firm performance in Italia.

Regarding board independence (BOIND), Leung et al. (2014) and Zattoni et al. (2017) stated that firm performance is improved when the number of non-executive directors is increased. Moreover, external directors are more concerned about their reputation, which motivates them to monitor the management closely and enhance the effectiveness of companies' operations. Afify (2009) claimed that management behaviour is effectively monitored by independent directors and it influences the level of control which also affects the timing of audit work. Moreover, Al Fadli et al. (2020) found that independent directors on the board encourage the companies to issue CSR information.

Another component that is argued to affect financial reporting quality is board meetings (BOME). Vafeas (1999) stated that a high number of board meetings is an important mechanism of the board of directors. Khan and Javid (2011) claimed that a high number of board meetings provides directors with respectful chances to choose among different decisions then getting early final results. Baatwah (2014) also claimed that frequent board meetings reflect the board efforts to protect the shareholders. Moreover, 
Al Farooque et al. (2019) found that a high number of board meetings increases the performance of firms in Thailand.

For the audit committee size (ACSIZ), it is argued that an effective audit committee is influenced by adequate resources in which a sufficient size of the audit committee is one of these resources. Nelson and Shukeri (2011) stated that a large audit committee can address the issues more effectively which helps to reduce the agency problem promptly. Madi et al. (2014) also reported that a large audit committee enhances corporate voluntary disclosure and decreases information asymmetry between the owners and management. Furthermore, Inaam and Khamoussi (2016) studied the effect of the audit committee on earnings management. Their study found that a large audit committee makes control of management and helps to reduce managers' misbehaviours. In a recent study, using a sample of 41 firms listed in the Colombo Stock Exchange, Balasundaram (2019) found that a large audit committee is associated with a high intellectual capital disclosure.

Regarding the audit committee independence (ACIND), previous studies stated that it is considered one of the fundamental monitoring tools. It is argued that an independent audit committee is the representative of the board to assess management performance (Alzharani \& Che-Ahmad, 2015; Alfraih, 2016). An independent audit committee is essential since its monitoring role influences the audit quality (Almuzaiqer, 2016). Alzeban and Sawan (2015) found evidence that the existence of an independent audit committee is associated with better implementation of the internal audit function. In the same context, Kallamu and Saat (2015) suggested that the independent audit committee is more likely to provide independent monitoring on the financial reporting process. Moreover, Oradi and Darjezi (2019) found that the independent audit committee reduces companies' ability to perform financial restatement in the context of Iranian companies.

Audit committee number of meetings (ACMEE) is used as a measure of audit committee activity (Abbott et al., 2004). Abbott et al. (2000) reported that US companies, which have more audit committee meetings, are less likely to engage in fraudulent reporting. Zábojníková (2016) found that the frequency of audit committee meetings is related to better performance in the UK. The author suggested that an active audit committee is considered as a better monitoring body. Likewise, Al-Okaily and Naueihed (2019) found that the frequency of audit committee meetings is positively associated with publicly traded firms' performance in Oman. They argued that an active audit committee can reduce information asymmetry that arises between managers and shareholders in these companies and improve information quality.

Furthermore, it is argued that the main responsibility of the audit committee expertise (ACEXP) is to monitor financial reporting progress. To achieve its responsibility, the members should have a minimum awareness of accounting or finance knowledge (The Blue-Ribbon Committee, 1999). Davidson et al. (2004) found that companies in the US, whose audit committee have an accounting expert, is positively associated with the stock price. They suggested that companies with an expert member in their audit committee are to be rewarded by the market. Moreover, Baatwah et al. (2019) found that an audit committee chair with accounting expertise helps in reducing the audit report lag in the context of Malaysia. They argued that the audit committee chair is the person who can solve client-auditor disputes by involving the client-auditor negotiation process. In another study, Karud et al. (2020) found that the audit delay is negatively associated with audit committee expertise. They argued that an expert audit committee can help the external auditor to complete their work in a timely basis.

It is also argued that firm size (SIZE) can influence financial reporting timeliness. Firth (1985), for instance, stated that the auditors of large companies can achieve their audit work early. This is because large companies have enough resources and are expected to hire more audit fees to higher-quality auditors 
to receive quality audit work conducted in a timely manner. Similarly, Habib and Bhuiyan (2011) and Rusmine and Evans (2017) argued that large companies sized have a greater influence on their external auditors to achieve their audit work quickly. They stated that large companies possess a strong internal control which will be easy for the external auditor to complete the audit work in a short time. Moreover, Elguindy and Basuony (2018) found that there is a negative relationship between firm size and earnings management. They argued that large firms are monitored by the government which lead to reducing the misbehaviours of the management. As such, the current study suggests that firm size (SIZE) is positively associated with financial reporting timeliness.

Firm profitability is another factor that affects financial reporting timeliness. It is used to assess the capability of a firm to generate earning. Abbott et al. (2012) stated that profitability reflects the good and bad news of the company suggesting that good news is published to users early. Furthermore, Alkhatiba \& Marjib (2012) also reported that firms suffering from losses are now willing to reports its bad performance and they reschedule their audit work which consequently leads to a late audit report. Moreover, Raweh et al. (2019) found evidence that profitable firms have enough money to pay professional audit firms to complete the audit work on a timely basis. This study suggests that firm profitability is positively related to financial reporting quality.

Finally, firm leverage also influences financial reporting timeliness (Jaggi \& Tsui,1999). It refers to the association between the company's liabilities and its assets. Companies with high debts compared to their assets are considered high leveraged. They can hire high-quality auditing services and need more auditing time (Harjoto et al., 2015). According to Carslaw and Kaplan (1991), the probability of a firm's failure is increased when the ratio of debt to total assets is increased. Thus, it is more likely that the announcement of the financial report will be delayed. Mishra and Kapil (2018) found that firm leverage in India is negatively associated with firm performance. They argued that it is less costly for Indian companies to manage their resources based on internal sources rather than the debt market. Following the previous studies, the current study suggests that financial reporting timeliness is negatively associated with firm leverage.

\section{RESULTS AND DISCUSSION}

Before running the regression analysis test, some assumptions should be met such as normality, multicollinearity, heteroscedasticity, and autocorrelation. The current study used the values of Skewness and Kurtosis statistics to detect the normality. Hair et al. (2006) and Leys et al. (2013) suggested that the thresholds of Skewness and Kurtosis are \pm 3 and \pm 10 respectively.

Table 4 shows that all variables are normally distributed, thus the normality assumption is met. 
Table 4: Descriptive statistics for continuous variables

\begin{tabular}{llllll}
\hline & Minimum & Maximum & Mean & Skewness & Kurtosis \\
\hline TRT & 21 & 165 & 70.5 & 0.122 & -0.934 \\
BOSIZ & 4 & 18 & 7.8 & 1.067 & 3.310 \\
BOME & 1 & 17 & 6.21 & 1.244 & 4.424 \\
BOIND & 0 & 1 & 0.71 & -0.273 & -0.934 \\
ACSIZE & 2 & 6 & 3.3 & 0.739 & -1.461 \\
ACIND & 0.33 & 1 & 0.83 & -1.048 & 0.045 \\
ACME & 0 & 12 & 4.76 & 0.987 & 1.743 \\
ACEXP & 0 & 1 & 0.34 & 0.396 & -0.192 \\
SIZE & $39,618,659$ & $128,284,105,000$ & $11,642,308,128$ & 0.114 & 0.010 \\
PROF & -0.99 & 0.76 & 0.03 & -1.150 & 4.013 \\
LEV & 0 & 1.03 & 0.39 & 0.954 & 3.401 \\
\hline
\end{tabular}

The heteroscedasticity problem was also tested. The efficient of regression estimation will be reduced and distorted when the heteroscedasticity problem exists. To detect a heteroscedasticity problem, Breusch-Pagan/Cook-Weisberg's test was applied. If P-value of the test is $<0.05$, the data is suffering from heteroscedasticity issue, and heteroscedasticity problem does not exist if it is $>0.05$ (Alrassas, 2015). the P-value of TRT models was 0.5060 as presented in Table 5. This implies that the TRT model is free from heteroscedasticity issue.

Table 5 Heteroscedasticity Test

\begin{tabular}{llll}
\hline \multicolumn{4}{l}{ Breusch-Pagan / Cook-Weisberg test for heteroskedasticity } \\
\hline \multicolumn{4}{l}{ H0: Constant variance } \\
\hline TRT & Chi2 (1)= 0.44 & Prob $>\mathrm{F}=0.5060$ \\
\hline
\end{tabular}

Autocorrelation is another problem that needs to be investigated before running a regression analysis. It is argued that the efficiency of the regression coefficient is reduced, and the regression estimations are inconsistence and biased when autocorrelation is existed (Gujarati \& Porter, 2009). To identify and detect the autocorrelation issue, Wooldridge test was applied in this study. According to Alrassas (2015), if P-value of Wooldridge test is < 0.05 , the data of the study is suffering from autocorrelation issue. Table 6 shows that the P-value of Wooldridge test was 0.0023 . This indicates that the TRT model is suffering from an autocorrelation problem. According to Khauola and Moes (2019), the autocorrelation problem is a common issue that exists in the panel data analysis. Consequently, Baatwah (2014) and Alrassas (2015) suggested the use of Robust standard errors method to solve the autocorrelation issue. Table 11 shows the results of the Robust standard errors method.

Table 6 Autocorrelation Test

\begin{tabular}{|c|c|c|}
\hline & Wooldridge test for & \\
\hline & H0: no first-order a & \\
\hline TRT & $F(1,58)=10.181$ & \\
\hline
\end{tabular}

\section{Descriptive statistics}

Table 4 shows the descriptive statistics of the variables used in the study. It can be seen from the table that the mean of TRT was 70.5 days with a minimum of 21 days and a maximum of 165 days. This result indicates that there was a variance among the listed companies. ADX and DFM require the listed 
companies to submit their financial statements within 90 days from the fiscal year-end. This evidence suggests that the UAE listed companies release their financial reports within the time frame. Compared to other emerging markets, it seems that the average of financial report delay in the UAE is shorter than the delay in Bahrain listed companies which are 85 days (Abdulla, 1996) and in Istanbul market which is 86 days (Türel, 2010). However, the result is similar to Afify (2009) who found evidence in Egypt that the lag of issuing financial statements is 67 days.

The board size is reported to have a range from 4 to 18 with a mean of 7.8 members. The findings also showed that the average of independent directors was 71 per cent ranging between 0 and 1 . This means that the UAE listed companies meet the requirement of code of corporate governance which require the listed companies to have at least the third independent directors on their board. In term of board meetings, the result showed that the average of board meetings was 6.61 ranged from 1 to 17 . For the audit committee size, the table presents that the average of audit committee size in the year was 3.3 ranged between 2 and 6 members. This results also meets the UAE code of corporate governance which required that the audit committee should comprise of at least three members. For the audit committee independence, the table shows that the average of audit committee independence was 0.83 and ranged between 0.33 and 1. This result also meets the requirement of the UAE code of corporate governance which require the listed companies to have at least two-third of independent audit committee members. For audit committee meetings, the results showed that

Regarding the controlled variables, it is revealed that companies' size was ranged between AED $39,618,659$ and $128,284,105,000$ MR with a mean of AED11,642,308,128. The range of profitability is from -0.99 to 0.76 with a range of 0.03 . Finally, firm leverage ranges from 0 to 1.03 with means of 0.39 .

\section{Correlation results}

Table 7 shows the correlation between AFEE and other variables. It appears that AFEE has a positive and significant correlation with BDSIZ, BDIND, BDMEE, SIZE, PROF, and LEVE at 1 per cent. BDSIZ has a significant positive correlation with SIZE and LEVE at 1 per cent. This means that the increase in board size corresponds with the increase in the total assets and firm leverage. BDIND was also observed to have a significant positive correlation with BDMEE, SIZE, and LEVE at 1 per cent. This indicates that a firm with a high proportion of board independent is correlated with more board meetings, high total assets, and high firm leverage. Moreover, the table shows that BDMEE was positively correlated with SIZE and LEVE at 1 per cent. This result indicates that the increase in board meetings corresponded with the increase in the total assets and firm leverage. The table also shows that SIZE has a positive correlation with LEVE at 1 per cent. This means that a company with high total assets is related to more firm leverage. Finally, it is presented that PROF has a positive significant correlation with LEVE at 1 per cent. This indicates that firm leverage is increased when the firm profitability is increased. Table 7 provides evidence that the highest correlation was between BDIND and ACIND at 0.440. This indicates that multicollinearity problem is absent since the correlation between the variables was less than \pm 0.90 (Pallant, 2001). 
Table 7: Pearson Correlations

\begin{tabular}{|c|c|c|c|c|c|c|c|c|c|c|c|c|}
\hline & TRT & ROYAL & BOSIZ & BOIND & BOMEE & ACSIZE & ACIND & ACME & ACEXP & SIZE & PROF & LEVE \\
\hline TRT & 1 & & & & & & & & & & & \\
\hline ROYAL & -0.300 & 1 & & & & & & & & & & \\
\hline BOSIZ & -0.024 & 0.245 & 1 & & & & & & & & & \\
\hline BOIND & -0.147 & $0.081 * *$ & $0.049^{* *}$ & 1 & & & & & & & & \\
\hline BOMEE & $0.089^{*}$ & -0.170 & $0.031^{* *}$ & 0.263 & 1 & & & & & & & \\
\hline ACSIZ & -0.111 & 0.105 & 0.375 & $0.061^{*}$ & $0.099^{*}$ & 1 & & & & & & \\
\hline ACIND & -0.171 & 0.280 & $0.079^{*}$ & 0.440 & $-0.073^{*}$ & $0.081^{*}$ & 1 & & & & & \\
\hline ACME & $0.057^{*}$ & $0.062^{*}$ & 0.271 & 0.159 & 0.340 & 0.205 & 0.113 & 1 & & & & \\
\hline ACEXP & -0.062 & -0.156 & $-0.071^{*}$ & -0.123 & $-0.060^{*}$ & -0.171 & $0.045^{* *}$ & $0.037^{* *}$ & 1 & & & \\
\hline SIZE & $0.042^{* *}$ & $0.093^{*}$ & 0.408 & 0.136 & 0.336 & 0.133 & $0.023^{* *}$ & 0.396 & -0.106 & 1 & & \\
\hline PROF & -0.259 & 0.103 & $0.057^{*}$ & $0.005^{* * *}$ & $-0.051^{*}$ & $0.083^{*}$ & $0.010^{* *}$ & $0.005^{* * *}$ & $0.010^{* * *}$ & 0.145 & 1 & \\
\hline LEVE & 0.187 & -0.260 & 0.155 & 0.132 & 0.331 & $-0.034^{* *}$ & $0.008^{* * *}$ & 0.285 & $0.004^{* * *}$ & 0.371 & -0.226 & 1 \\
\hline
\end{tabular}

TRT = Total Report Timeliness, ROYAL = Royal Family Member, BOSIZ= Board Size, BOIND= Board Independence, BOME= Board Meeting, ACSIZ= Audit

committee size, ACIND= Audit committee independent, ACME= Audit Committee Meetings, ACEXP= Audit Committee Expertise, SIZE= Firm Size, PROF= Firm Profitability, LEVE= Firm Leverage

* Significant at 0.10 level ${ }^{* *}$ Significant at 0.05 level ${ }^{* * *}$ Significant at 0.01 level 
Table 7 illustrates the correlation between total report timeliness (TRT) and other variables. The table shows that the existence of Royal family members (RFM) on the board is negatively associated with the total report timeliness (TRT). The table also provides evidence that the highest correlation is between profitability (PROF) and leverage (LEVE) at 0.4. According to Pallant (2001), this means that there is no existence of the multicollinearity problem as the highest correlation was less than \pm 0.9 .

\section{Multiple regression results}

Table 8 presents the results of multiple regression. It can be seen that the F-statistics is significantly different from zero which means that the independent variables explain the variation of TRT about its mean. The R2 value was 15 per cent which means that the model explains only 15 per cent of the variation of TRT.

The finding showed that the existence of Royal family members (ROYAL) on the board is negatively related with FRL at 1 per cent. This result indicates that companies that have at least one Royal family member on its board have less financial reporting lag and submit its financial reports early. This finding also infers that Royal family members could help the board of directors to supervise the management effectively and improve the financial reporting quality. This result is in line with Alzharani and Che- Ahmad's (2015) study who found that the existence of Royal family members on the board enhances the firm performance. The board size (BOSIZ) and board meetings (BOME) were found to have an insignificant association with TRT. This result is consistent with Habib et al. (2018) who found no evidence that the board size and board meetings affect audit timeliness. Board independence (BOIND) was found to have a negative association with TRT at 10 per cent. This suggests that the more nonexecutive members, the less lag of financial reports submission. This finding supports the idea that an independent board implements strong monitoring which thereby influences the extent and timing of audit work, and subsequently the time of issuing the financial reports. This result is in line with Afify's (2009) who found that there is a negative relationship between the independent board and audit delay.

In term of the audit committee size (ACSIZ), it is reported that ACSIZE is negatively associated with TRT at 5 per cent. This means that the larger the audit committee, the shorter the time needed to issue the financial reports. This result is in line with the idea that a large audit committee size has sufficient resources and effectively addresses the problems faced by the company. This finding supports Naimi et al.'s (2010) who found that companies with large audit committee sizes are more likely to produce timely financial reports.

Regarding the audit committee meetings (ACME) and audit committee independence (ACIND), they were found to have an insignificant association with TRT. These results are consistent with Almuzaiqer et al.'s (2018) and Raweh et al.'s (2019) who found no evidence that the audit committee meetings and audit committee independence are associated with financial reporting timeliness. In light with the expectation of the study, the findings showed that audit committee expertise (ACEXP) is negatively associated with TRT at 1 per cent level. This result is in line with Habib et al.'s (2018), Raweh et al.'s (2019), and Karoud et al.'s (2020) in which they argued that the expert members have a role to maintain financial reporting integrity and they are more skilled to discover fraud and opportunistic behaviours early which can lead to issuing the financial reports in a short time.

Profitability (PROF) was also found to have a negative significant association with TRT at 1 per cent level. It suggests that companies with higher profitability are expected to issue their financial reports to the public faster than lower profitable companies. This finding is in consistence with the notion that a company requests the external auditor to complete its job as early as possible to convey the good news to the public. This result is also consistent with Ashton et al.'s (1989) and Afify's (2009) who found that 
firm profitability enhances financial reporting timeliness. The findings revealed that there is an insignificant association between financial reporting timeliness and firm size (SIZE) and firm leverage (LEVE).

Table 8: Multiple Regression Results

\begin{tabular}{lccc}
\hline Variable & Coefficients & t-value & p-value \\
\hline ROYAL & -11.22345 & -3.21 & $0.001^{* * *}$ \\
BOSIZ & .3867269 & 0.54 & 0.592 \\
BOIND & -11.47787 & -1.78 & $0.075^{*}$ \\
BOMEE & 1.132136 & 1.61 & 0.108 \\
ACSIZ & -4.145318 & -2.06 & $0.039^{* *}$ \\
ACIND & -7.539101 & -1.16 & 0.246 \\
ACME & .9605739 & 1.32 & 0.187 \\
ACEXP & -11.95851 & -2.57 & $0.010^{* * * *}$ \\
SIZE & 1.57243 & 0.65 & 0.515 \\
PROF & -44.91713 & -4.41 & $0.000^{* * * *}$ \\
LEVE & -2.12287 & -0.32 & 0.750 \\
\hline N & 437 & & 0.000 \\
F Value & 9.75 & & \\
R Square & 0.1909 & & \\
\hline
\end{tabular}

TRT $=$ Total Report Timeliness, ROYAL $=$ Royal Family Member ,BOSIZ= Board Size, BDIND= Board Independence,

$\mathrm{BDME}=$ Board number of meetings, $\mathrm{ACSIZ}=$ Audit committee size, $\mathrm{ACIND}=$ Audit committee independent, $\mathrm{ACME}=$

Audit committee number of meetings, ACEXP= Audit committee accounting expertise, SIZE= Firm Size, PROF= Firm

Profitability, LEVE= Firm Leverage

* Significant at 0.10 level $\quad{ }^{* *}$ Significant at 0.05 level $\quad{ }^{* * *}$ Significant at 0.01 level

Additional tests were conducted to ensure that the results of the study are not sensitive to the research design. The first test is regarding the timeliness measurement. The current study used a total reporting timeliness (TRT) to measure financial reporting timeliness. By using the same sample, the audit report lag (ARL) was applied as a measure of timeliness to ensure the robustness of the main results. Table 9 shows that RFM, ACSIZE, ACEXP and PROF have a significant effect on ARL. The main results showed that BDIND has a significant effect on TRT, whereas it has been shown to have an insignificant effect on ARL. In general, the majority of robust results are similar to the main results and this provides robustness of the main results 
Table 9: Additional Multiple Regression Results by using ARL as a proxy of financial reporting timeliness

\begin{tabular}{|c|c|c|c|}
\hline Variable & Coef & t-value & p-value \\
\hline ROYAL & -8.575657 & -2.46 & $0.014^{* *}$ \\
\hline BOSIZ & 0.388527 & 0.57 & 0.567 \\
\hline BOIND & -6.332433 & -1.05 & 0.292 \\
\hline BOME & 0.7167412 & 1.12 & 0.261 \\
\hline ACSIZ & -3.217871 & -1.77 & $0.077^{*}$ \\
\hline ACIND & -9.332801 & -1.55 & 0.121 \\
\hline ACME & 0.2486365 & 0.38 & 0.706 \\
\hline ACEXP & -7.914843 & -1.86 & $0.063^{*}$ \\
\hline SIZE & 3.59684 & 1.47 & 0.141 \\
\hline PROF & -44.30247 & -4.87 & $0.000^{* * *}$ \\
\hline LEVE & -1.361383 & -0.22 & 0.829 \\
\hline $\mathrm{N}$ & 437 & & 0.000 \\
\hline F Value & 8.22 & & \\
\hline R Square & 0.155 & & \\
\hline \multicolumn{4}{|c|}{$\begin{array}{l}\text { TRT }=\text { Total Report Timeliness, ROYAL }=\text { Royal Family Member }, \text { BOSIZ }=\text { Board Size, BOIND= Board Independence, } \\
\text { BOMEE }=\text { Board number of meetings, ACSIZ= Audit committee size, ACIND= Audit committee independent, ACME= } \\
\text { Audit committee number of meetings, ACEXP = Audit committee accounting expertise, SIZE }=\text { Firm Size, PROF= Firm } \\
\text { Profitability, LEVE }=\text { Firm Leverage }\end{array}$} \\
\hline
\end{tabular}

$$
\text { *Significant at } 0.10 \text { level, **Significant at } 0.05 \text { level, ***Significant at } 0.01 \text { level }
$$

Moreover, the current study also used a dichotomic approach to measure the independent variable instead of a continuous approach. Table 10 shows that RFM, BDIND, ACEXP and PROF have a significant effect on TRT. The findings also showed that BDIND significantly affects TRT in the robustness test. However, Table 8 shows that BDIND does not affect TRT. BDSIZE is also presented to have a significant effect on TRT on the main results and an insignificant effect on TRT on the robustness results. Generally, most of the results are as similar to the main results. Therefore, it gives robustness of the main results 
Table 10: Additional Multiple Regression Results of TRT model by using dichotomic measures of independent variables

\begin{tabular}{lccc}
\hline Variable & Coefficients & t-value & $\mathrm{p}$-value \\
\hline ROYAL & -13.3525 & -3.81 & $0.000^{* * *}$ \\
BOSIZ & 2.786489 & 0.96 & 0.339 \\
BOIND & -4.559599 & -1.67 & $0.095^{*}$ \\
BOME & 3.64546 & 1.49 & 0.135 \\
ACSIZ & -4.177625 & -1.54 & 0.124 \\
ACIND & -1.741531 & -0.65 & 0.516 \\
ACME & 2.296424 & 0.92 & 0.356 \\
ACEXP & -6.044725 & -2.36 & $0.018^{* *}$ \\
SIZE & .8709736 & 0.25 & 0.801 \\
PROF & -5.617316 & -2.50 & $0.013^{* *}$ \\
LEVE & -2.780182 & -1.02 & 0.307 \\
\hline N & 437 & 0.000 \\
F Value & 7.99 & & \\
R Square & 0.1585 & & \\
TRT= Total Report Timeliness, ROYAL $=$ Royal Family Member, BOSIZ= Board Size, BOIND= Board Independence, \\
BDME= Board number of meetings, ACSIZ= Audit committee size, ACIND= Audit committee independent, ACME= \\
Audit committee number of meetings, ACEXP= Audit committee accounting expertise, SIZE= Firm Size, PROF= Firm \\
Profitability, LEVE= Firm Leverage \\
\hline
\end{tabular}

${ }^{*}$ Significant at 0.10 level $\quad{ }^{* *}$ Significant at 0.05 level ${ }^{* * *}$ Significant at 0.01 level

Finally, it has been shown in Table 6 that the data of this study is suffering from the autocorrelation issue. It was suggested earlier that the robust standard errors method is the best common method applied to solve this problem. The results of robust standard errors method are shown in Table 11. It can be seen from the table that all results of the test, except for BDMEE, are similar to the main results. This suggests that the robust standard errors method had overcome the autocorrelation problem in the TRT model 
Table 11: Robust Results of TRT Model

\begin{tabular}{|c|c|c|c|c|c|c|}
\hline \multirow[t]{2}{*}{ Variable } & \multicolumn{3}{|c|}{ Robust Results } & \multicolumn{3}{|c|}{ Mean results } \\
\hline & Coef & $\mathrm{t}$-value & $p$-value & Coef & t-value & $p$-value \\
\hline ROYAL & -11.22345 & -3.00 & $0.003^{* * *}$ & -11.22345 & -3.21 & $0.001^{* * *}$ \\
\hline BOSIZ & .3867269 & 0.52 & 0.603 & .3867269 & 0.54 & 0.592 \\
\hline BOIND & -11.47787 & -1.73 & $0.083^{*}$ & -11.47787 & -1.78 & $0.075^{*}$ \\
\hline BOME & 1.132136 & 1.75 & $0.081^{* *}$ & 1.132136 & 1.61 & 0.108 \\
\hline ACSIZ & -4.145318 & -2.25 & $0.025^{* *}$ & -4.145318 & -2.06 & $0.039^{* *}$ \\
\hline ACIND & -7.539101 & -0.94 & 0.348 & -7.539101 & -1.16 & 0.246 \\
\hline ACME & .9605739 & 1.07 & 0.286 & .9605739 & 1.32 & 0.187 \\
\hline ACEXP & -11.95851 & -2.40 & $0.017^{* *}$ & -11.95851 & -2.57 & $0.010^{* * *}$ \\
\hline SIZE & 1.57243 & 0.79 & 0.430 & 1.57243 & 0.65 & 0.515 \\
\hline PROF & -44.91713 & -4.90 & $0.000^{* * *}$ & -44.91713 & -4.41 & $0.000^{* * *}$ \\
\hline LEVE & -2.12287 & -0.25 & 0.799 & -2.12287 & -0.32 & 0.750 \\
\hline $\mathrm{N}$ & 437 & & & & & \\
\hline F Value & 15.40 & & & & & \\
\hline R Square & 0.1909 & & & & & \\
\hline $\begin{array}{l}\text { TRT }= \\
\text { BDME } \\
\text { ACME } \\
\text { PROF= }\end{array}$ & $\begin{array}{l}\text { t Timeliness } \\
\text { number of } \\
\text { ommittee nu } \\
\text { tability, LE }\end{array}$ & $\begin{array}{l}\mathrm{L}=\mathrm{Ro} \\
\text { s, ACS } \\
\text { f meetir } \\
\text { n Lever }\end{array}$ & $\begin{array}{l}\text { ily Meml } \\
\text { Audit cor } \\
\text { EXP= A }\end{array}$ & $\begin{array}{l}\mathrm{IZ}=\text { Board } \mathrm{S} \\
\text { ize, ACIN } \\
\text { mittee acco }\end{array}$ & $\begin{array}{l}\text { IND = B } \\
\text { dit comr } \\
\text { expertise }\end{array}$ & $\begin{array}{l}\text { Idependen } \\
\text { independe } \\
=\text { Firm Si }\end{array}$ \\
\hline
\end{tabular}

\section{CONCLUSION}

The main objective of this study is to examine the relationship between the existence of Royal family members on the board of directors and financial reporting quality. Financial reporting timeliness was used as a measurement of financial reporting quality and total reporting lag was used as a proxy of financial reporting timeliness. 437 observations were used in the current study from the companies listed in ADX and DFM markets for the years of 2011-2018. The data were collected from the annual reports. Ten control variables are determined to affect financial reporting timeliness, namely board size, board independence, board meetings, audit committee size, audit committee independence, audit committee meetings, audit committee expert firm size, firm performance, and firm leverage. The main findings showed that the existence of Royal family members on the board is related to shorter financial reporting lag and higher financial reporting quality.

The findings also showed that the four control variables, namely board independence, audit committee size, audit committee expertise, and firm profitability have a negative association with financial reporting lag. This indicates that firms with an independent board of directors, large audit committee, audit committee with accounting expert and high profit take a shorter time to issue their financial reports to the public. On the other hand, this study also has some limitations. Firstly, financial companies were excluded from this study as they are following different regulations and principles. Future studies may include testing the relationship between the existence of Royal family members and financial reporting timeliness with wider sectors including the financial sector. Secondly, the annual reports were used as the only resources to collect the data. Future studies may extend the research methods of collecting and analysing the data by using alternative tools such as survey and interviews with Royal family members and the management. The alternative methods may strengthen the findings of the study. Thirdly, this study used a dummy variable to measure the Royal family members. A proportion of Royal family members on the board is another proxy that may be considered by future research. Finally, although the quality of financial 
reporting is a broad concept, the current study used financial reporting timeliness as a proxy of financial reporting quality following the concept developed by Nelson and Shukri (2011), Hassan (2016), and Baatwah et al. (2019). Other proxies may be used in future studies as an indicator of financial reporting quality such as earnings management or audit quality.

Furthermore, there are many unique issues in the UAE to be addressed by future studies in the context of financial reporting timeliness such as the power of Royal family members in using the CEO positions. Future studies may replicate this study and test the validity of this model by using different countries with different sample sizes in different periods. Practically, the results of this study can benefit the policymakers and regulators in the UAE such as the Securities and Commodities Authority (SCA) and the Ministry of Economy. Since the findings of the study indicated that the board mechanisms and audit committee mechanisms influence the financial reporting timeliness, the UAE listed companies may be enforced by the regulators to apply the best practices and improve the financial reporting quality. Moreover, the findings of this study will be interesting for the academic community and researchers because of the lack of research addressing financial reporting quality in the UAE. Lastly, financial analysts and investors depend on the audited financial reports in making decisions related to the investment in the UAE.

\section{REFERENCES}

Abbott, L., Parker, S., Peters, G. and Raghunandan, K. (2004), “The association between audit committee characteristics and audit fees", Auditing: A Journal of Practice \& Theory, 22 (2), 17-32.

Abbott, L. J., Park, Y., \& Parker, S. (2000). The effects of audit committee activity and independence on corporate fraud. Managerial Finance. 26 (11), 55-67

Abbott, L. J., Parker, S., \& Peters, G. F. (2012). Internal audit assistance and external audit timeliness. Auditing: A Journal of Practice \& Theory, 31(4), 3-20.

Abdulla, J.Y.A. (1996), "The timeliness of Bahraini annual reports”, Advances in International Accounting, 9. 73-88.

Afify, H. A. E. (2009). Determinants of audit report lag: Does implementing corporate governance have any impact? Empirical evidence from Egypt. Journal of Applied Accounting Research, 10 (1). 56-86.

Al-Adeem, K., \& Al-Sogair, I. Y. (2019). Effectiveness of the board of directors in monitoring executive management: preliminary evidence from Saudi Arabia. Journal of Governance and Regulation / Volume, 8 (3).82-82

Al-Ajmi, J. (2008). Audit and reporting delays: Evidence from an emerging market. Advances in Accounting, 24 (2). 217-226.

Alazzani, A., Aljanadi, Y., \& Shreim, O. (2019). The impact of existence of royal family directors on corporate social responsibility reporting: a servant leadership perspective. Social Responsibility Journal. 15 (1), pp. 120-136

Alghamdi, S., A. (2012). Investigation into earnings management practices and the role of corporate governance and external audit in emerging markets: Empirical evidence from Saudi listed companies (Doctoral dissertation). Business School, Durham University.

Al Fadli, A., Sands, J., Jones, G., Beattie, C. and Pensiero, D. (2020), "Board independence and CSR reporting: pre and post analysis of JCGC 2009", International Journal of Law and Management, 62 (2). 117-138.

Al Farooque, O., Buachoom, W. and Sun, L. (2019), "Board, audit committee, ownership and financial performance - emerging trends from Thailand", Pacific Accounting Review, 32 (1). 54-81

Alfraih, M. M. (2016). The effectiveness of board of directors' characteristics in mandatory disclosure compliance. Journal of Financial Regulation and Compliance, 24 (2), pp. 154-176. 
Alkhatib, K., \& Marji, Q. (2012). Audit reports timeliness: Empirical evidence from Jordan. ProcediaSocial and Behavioral Sciences, 62. 1342-1349.

Al-muzaiqer, M. A. H. (2016). The impact of audit committee effectiveness on Audit Report Lag; Evidence from UAE (Unpublished Master's thesis). Kulliyyah of Economic and Management science, International Islamic University Malaysia.

Almuzaiqer, M. A. (2018). Timeliness of financial reporting and audit committee effectiveness: evidence from UAE. UNIMAS Review of Accounting and Finance, 1 (1). 99-112.

Al-Rassas, A. H. (2015). Internal monitoring mechanisms and earnings quality: Empirical evidence from Malaysia (Doctoral dissertation, Universiti Utara Malaysia.

Al-Rassas, A. H., \& Kamardin, H. (2015). Internal and external audit attributes, audit committee characteristics, ownership concentration and earnings quality: Evidence from Malaysia. Mediterranean Journal of Social Sciences, 6 (3). 458-470.

Al-Okaily, J. and Naueihed, S. (2019), "Audit committee effectiveness and family firms: impact on performance", Management Decision, 58 (6). 1021-1034.

Alzeban, A., \& Sawan, N. (2015). The impact of audit committee characteristics on the implementation of internal audit recommendations. Journal of International Accounting, Auditing and Taxation, No. 24, pp. 61-71.

Alzharani, A. M., \& Che-Ahmad, A. (2015). Royal Family Members and Firm Performance: Evidence from Kingdom of Saudi Arabia. Accounting \& Taxation, 7 (2). 29-42.

Arioglu, E. (2020), "Female board members: the effect of director affiliation", Gender in Management: An International Journal , 35 (2). 225-254.

Ashton, R. H., Graul, P. R., \& Newton, J. D. (1989). Audit delay and the timeliness of corporate reporting. Contemporary Accounting Research, 5 (2). 657-673.

Baatwah, S., Salleh, Z. and Stewart, J. (2019), "Audit committee chair accounting expertise and audit report timeliness: The moderating effect of chair characteristics", Asian Review of Accounting, 27 (2). 273-306.

Baatwah, S. R. A. (2014). The Effect of Culture, Corporate Governance Quality, And Management Characteristics On The Timeliness of Financial Reporting: Evidence From Oman (Unpublished Doctorate thesis). College of Business, University Malaysia Terengano.

Balasundaram, N. (2019). Audit committee characteristics and their impact on intellectual capital disclosure: a study of listed manufacturing companies in sri lanka. Asia-Pacific Management Accounting Journal, 14 (1). 135-149.

Bamber, E. M., Bamber, L.S, \& Schoderbek, M. P. (1993). Audit structure and other determinants of audit report lag: an empirical analysis. Auditing. A Journal of Practice and Theory, 1 (1). 1-23.

Beest, F. V., Braam, G. J. M., \& Boelens, S. (2009). Quality of Financial Reporting: measuring qualitative characteristics. http://www.ru.nl/nice/workingpapers.

Blue Ribbon Committee (BRC). (1999). Report and recommendations of the Blue Ribbon Committee on improving the effectiveness of corporate audit committee. New York: New York Stock Exchange and National Association of Securities Dealers.

Carslaw, C., \& Kaplan, S. (1991). An examination of audit delay: further evidence from New Zealand. Accounting and Business Research, 22 (85). 21-32

Clark, T. (Ed.) (2004), Theories of Corporate Governance (pp. 1-31), New York: Routledge. Code of Corporate Governance in Saudi Arabia. Available at: http://www.cma.org.sa/ Ar/Pages/Implementing

Davidson III, W. N., Xie, B., \& Xu, W. (2004). Market reaction to voluntary announcements of audit committee appointments: The effect of financial expertise. Journal of Accounting and Public Policy, Vol 23 No. 4, pp. 279-293.

El Guindy, M. N., \& Basuony, M. A. (2018). Audit firm tenure and earnings management: The impact of changing accounting standards in UK firms. The Journal of Developing Areas, 52 (4). 167-181. 
Fama, E.F. and Jensen, M.C. (1983),"Separation of ownership and control”. Journal of Law and Economics. 2. 301-325.

Firth, M. (1985), “An analysis of audit fees and their determinants in NewZealand”. Auditing: A Journal of Practice \& Theory, 4 (2). 23-37.

Ghazali, N. (2010). Ownership structure, corporate governance and corporate performance in Malaysia. International Journal of Commerce and Management, 20 (2). 109-119.

Gujarati, D. N., and D. C. Porter. (2009). Basic econometrics. 5th ed. New York: McGraw-Hill/Irwin.

Habib, A., \& Bhuiyan, M. B. U. (2011). Audit firm industry specialization and the audit report lag. Journal of international accounting, auditing and taxation, 20 (1). 32-44.

Habib, A., Bhuiyan, M. B. U., Huang, H. J., \& Miah, M. S. (2018). Determinants of audit report lag: A meta-analysis. International Journal of Auditing, 23 (1). 20-44.

Habtoor, O. S., \& Ahmad, N. (2017). The influence of royal board of directors and other board characteristics on corporate risk disclosure practices. Corporate Ownership \& Control, 14 (2). $326-$ 337.

Hair, J. F., Black, W. C., Babin, B. J., Anderson, R. E., \& Tatham, R. L. (2006). Multivariate data analysis (6thed.). Upper Saddle River, N.J. Pearson Education Inc.

Harjoto, M., Laksmana, I., \& Lee, R. (2015). Board diversity and corporate social responsibility. Journal of Business Ethics, 132 (4), pp. 641-660.

Hassan, Y. M. (2016). Determinants of audit report lag: evidence from Palestine. Journal of Accounting in Emerging Economies, 6 (1). 13-32.

Inaam, Z., \& Khamoussi, H. (2016). Audit committee effectiveness, audit quality and earnings management: a meta-analysis. International Journal of Law and Management, 58 (2). 179-196.

International Accounting Standards Board. (2018). The Conceptual Framework for Financial Reporting 2018. IFRS.

Jaggi, B., \& Tsui, J. (1999). Determinants of audit report lag: Further evidence from Hong Kong. Accounting and business research, 30 (1), pp. 17-28.

Kallamu, B.S., \& Saat , N. A. M. (2015). Audit Committee Attributes and firm performance: evidence from Malaysian finance companies. Asian Review of Accounting, 23 (3). 206-231

Kaaroud, M.A., Mohd Ariffin, N. and Ahmad, M. (2020), "The extent of audit report lag and governance mechanisms: Evidence from Islamic banking institutions in Malaysia", Journal of Islamic Accounting and Business Research, 11 (1). 70-89.

Khaoula, F., \& Moez, D. (2019). The moderating effect of the board of directors on firm value and tax planning: Evidence from European listed firms. Borsa Istanbul Review, 19 (4). 331-343.

Leung, S., Richardson, G., \& Jaggi, B. (2014). Corporate board and board committee independence, firm performance, and family ownership concentration: An analysis based on Hong Kong firms. Journal of Contemporary Accounting \& Economics, 10 (1). 16-31

Leys, C., Ley, C., Klein, O., Bernard, P., \& Licata, L. (2013). Detecting outliers: Do not use standard deviation around the mean, use absolute deviation around the median. Journal of Experimental Social Psychology, 49 (4). 764-766.

López, M. (2013), Elite Theory. Sociopedia.isa. Available at: www.sagepub.net/isa/admin/view PDF.aspx?\&art=Elitetheory.pdf.

Madi, H. K., Ishak, Z., \& Manaf, N. A. A. (2014). The impact of audit committee characteristics on corporate voluntary disclosure. Procedia-social and behavioral sciences, No. 164, pp. 486-492.

Merendino, A., \& Melville, R. (2019). The board of directors and firm performance: empirical evidence from listed companies. Corporate Governance: The International Journal of Business in Society. 19 (3). 508-551.

Mishra, R.K. and Kapil, S. (2018), "Board characteristics and firm value for Indian companies", Journal of Indian Business Research, 10 (1), pp. 2-32. 
Naimi, M., Nor, M., Rohami, S., \& Wan-Hussin, W. N. (2010). Corporate governance and audit report lag in Malaysia. Asian Academy of Management Journal of Accounting and Finance, 6 (2). 57-84.

Nelson, S. P., \& Shukeri, S. N. (2011). Corporate governance and audit report timeliness: evidence from Malaysia. Research in Accounting in Emerging Economies, No. 11, pp. 109-127.

Oradi, J. and Izadi, J. (2019), "Audit committee gender diversity and financial reporting: evidence from restatements", Managerial Auditing Journal, 35 (1). 67-92.

Pallant, J. (2001). SPSS Survival Manual: A Step by Step Guide to Data Analysis Using SPSS for Windows (Versions 10 and 11): SPSS Student Version 11.0 for Windows. Milton Keynes, UK, USA: Open University Press.

Peterson, J. E. (2001). Rulers, Merchants and Shaikhs in Gulf Politics. The Function of Family Networks", in The Gulf Family: Kinship Policies and Modernity, edited by Alanoud Alsharekh (London: Saqi Books, 2007), 21-36.

Raweh, N. A. M., Kamardin, H., \& Malik, M. (2019). Audit Committee Characteristics and Audit Report Lag: Evidence From Oman. International Journal of Accounting and Financial Reporting, 9 (1). 152169.

Rusmin, R., \& Evans, J. (2017). Audit quality and audit report lag: case of Indonesian listed companies. Asian Review of Accounting, 25 (2).191-210.

Türel, A. G. (2010). Timeliness of financial reporting in emerging capital markets: Evidence from Turkey. European Financial and Accounting Journal, 5 (3). 113-133.

Vafeas, N. (1999). Board meeting frequency and firm performance. Journal of financial economics, 53 (1). 113-142.

Yasin, F. M., \& Nelson, S. P. (2012). Audit committee and internal audit: implications on audit quality. International. Journal of Economics, Management and Accounting, 20 (2). 187-218.

Zábojníková, G. (2016). The Audit Committee Characteristics and Firm Performance: Evidence from the UK. (Unpublished Master's dissertation). College of Ecomomic, University Port.

Zattoni, A., Witt, M. A., Judge, W. Q., Talaulicar, T., Chen, J. J., Lewellyn, K., \& Shukla, D. (2017). Does board independence influence financial performance in IPO firms? The moderating role of the national business system. Journal of World Business, 52 (5). 628-639. 